\title{
A study on Differences between Parental Support System and Dimensions of Identity Development among Adolescents
}

\author{
G. Swarupa Rani ${ }^{1 *}$, Dr. M. Sarada Devi ${ }^{2}$
}

\section{ABSTRACT}

The aim of this investigation was to identify the differences between parental support system and dimensions of identity development among adolescents. A sample number of 120 adolescents belonging to different age groups from schools and colleges were selected for the study. Parental Support Scale developed by Dr. Niveditha Sharma and Nimmi Khare (2002) and questionnaire developed by Cheek and Briggs (2013) on aspects of identity development was used for data collection. Results indicate that, there were significant differences found in the mean scores of perceived parental support system and identity development of adolescents and further the results also shows the significant differences between two variables such as identity and the dimensions of parental support system i.e. parental interest and parental resource provision. Which means the adolescents who are receiving high parental support in terms of parental interest and parental resource provision had high mean scores on aspects of identity development such as social, relational and collective identity.

Keywords: Identity, Identity Development, Parents, Parents Support.

Adolescence is a transitional period of growth and change including the development of mature forms of thought, emotion and behavior. Identity construction is a unique time in every adolescent's life. Noteworthy stage theorist, Erik Erikson(1968), has illustrated the importance of identity formation in adolescents lives, further asserting that the age old question of 'who place themselves into hypothetical situations to help them find the best 'fit' with regard to identities; they're great at using their imaginations to envision how others will see them upon the changes they enact.

This is a transitional period in life characterized by physiological, cognitive, biological, emotional, and hormonal changes. Lot of time and energy are invested on their part to reach this important goal as it goes the distance to fulfill their sense of belonging and accomplishment.

\footnotetext{
${ }^{1}$ Ph.D scholar, Dept. of HDFS, C.H.Sc, Hyderabad, India

${ }^{2}$ Professor \& Head of HDFS Dept, C.H.Sc, Hyderabad. India

*Responding Author

(C) 2016 I G Rani, M Devi; licensee IJIP. This is an Open Access Research distributed under the terms of the Creative Commons Attribution License (http://creativecommons.org/licenses/by/2.0), which permits unrestricted use, distribution, and reproduction in any Medium, provided the original work is properly cited.
} 


\section{A study on Differences between Parental Support System and Dimensions of Identity Development among Adolescents}

Erikson impresses upon society that this is a highly mental and social process, rolling cues from the environment, opinions, observations, and reactions from friends and family into making the decision of which steps to take to find out who they are or in which direction to proceed (Schmitt et al., 2008).

According to Erikson (1968) the family helps in orienting children toward roles that are expected out of them at different stages of their lives. Furthermore, Rana and Shirali (2010) explained that family plays a critical role in adolescent identity formation by clarifying their confusion about change and transition. Based on the fact that parents serve as primary socializers of their children (Phinney \& Reis, 2009), there is increasing evidence that along with parenting practices and parental support have strong influences on adolescent identity formation (Bartle-Haring, 1997; Grotevant, 1998; Sartor \& Youniss, 2006).

Parental support is one of the most important contribution parents can make to the adolescents development. Greater the parents support, greater the social competence (self-esteem, moral behaviour, academic achievement and vocational development). Support can be shown in several ways such as physical affection, companionship and sustained contact. It is the crucial period adolescents struggle for their own identity. They are progressing into a period of maturation that is uncertain. They need guidance and strong support that comes from their parents.

\section{METHOD}

\section{Selection of sample}

- Purposive sampling procedure was used to select sample for the present study

- Sample comprised of 120 adolescents with equal number of boys and girls were selected for the study.

\section{Sampling procedure}

Criteria for sample selection are:

1. Age range of adolescents should be between 13-21 years.

2. Students studying schools and colleges were selected for the study.

Table-1 Details about distribution of sample

\begin{tabular}{|l|l|l|l|l|}
\hline S.No & Age & Boys & Girls & Total \\
\hline 1 & $13-15$ (early adolescents) & 20 & 20 & 40 \\
\hline 2 & $15-17$ years (Middle Adolescents) & 20 & 20 & 40 \\
\hline 3 & $17-21$ years (later adolescents) & 20 & 20 & 40 \\
\hline \multicolumn{2}{|l|}{ Total } & 60 & 60 & 120 \\
\hline
\end{tabular}




\section{Measurement Tools:}

In order to find out the mean differences between parental support system and dimensions of identity development among adolescents two scales were used. To find out the adolescents perceptions on parental support system, a scale developed by Dr.Niveditha Sharma and Nimmi Khare (2002) and questionnaire developed by Cheek and Briggs (2013) on aspects of identity development was used for data collection. The parental support system scale has 30 items measures three areas.

1. Parental interest

2. Parental behavior

3. Resource provision

An aspect of identity questionnaire by Cheek and Briggs (2013) was used to test the identity development of adolescents. The scale consists of 45 items and were divided into four subscales as

1. Personal identity orientation

2. Relational identity orientation

3. Social identity orientation

4. Collective identity orientation

\section{Procedure:}

The adolescents belonging to three different categories (early, middle and later adolescents) were purposefully selected from schools and colleges of Hyderabad city. The collected data was coded and analyzed using one way ANOVA test to calculate the mean differences between adolescents identity and parental support system.

\section{RESULTS}

The present investigation was undertaken with the objective of studying the mean differences between parental support system and dimensions of identity development among adolescents. The results of the study were described below. 
Table-2 Mean difference between parental support system and dimensions of identity development of adolescents $\quad(\mathrm{N}=120)$

\begin{tabular}{|l|l|l|l|l|l|l|l|l|l|l|l|}
\hline SI.No & $\begin{array}{l}\text { Dimensions } \\
\text { of parental } \\
\text { support } \\
\text { system }\end{array}$ & $\begin{array}{l}\text { Personal } \\
\text { identity }\end{array}$ & \multicolumn{2}{l|l|}{$\begin{array}{l}\text { Relational } \\
\text { identity }\end{array}$} & \multicolumn{2}{l|}{$\begin{array}{l}\text { Social } \\
\text { identity }\end{array}$} & \multicolumn{2}{l|}{$\begin{array}{l}\text { Collective } \\
\text { identity }\end{array}$} & F value \\
\cline { 3 - 10 } & Mean & S.D & Mean & S.D & Mean & S.D & Mean & S.D & \\
\hline 1 & $\begin{array}{l}\text { Parental } \\
\text { Interest }\end{array}$ & 2.82 & 0.502 & 2.46 & 0.564 & 2.80 & 0.504 & 2.35 & 0.4354 & $0.036112^{*}$ \\
\hline 2 & $\begin{array}{l}\text { Parental } \\
\text { Behaviour }\end{array}$ & 2.76 & 0.574 & 2.59 & 0.510 & 2.72 & 0.509 & 2.49 & 0.5132 & 0.104329 \\
\hline 3 & $\begin{array}{l}\text { Parental } \\
\text { Resource } \\
\text { provision }\end{array}$ & 2.53 & 04882 & 2.70 & 0.532 & 2.79 & 0.596 & 2.60 & 0.5974 & $0.002314^{*}$ \\
\hline
\end{tabular}

$* \mathbf{P},>0.05 ; * * \mathbf{P},>0.01$

It was evident from the table that there were significant differences found in the mean scores between the perceived parental support system and identity development of adolescents. Results depicted positive and significant differences noticed in two of the dimensions of parental support system i.e. parental interest and parental resource provision.

Adolescents who are receiving their parents interest in various aspects of their life, had high mean scores on personal and social identity development compared to adolescents who perceived less satisfaction with their parents behaviours. This might be due to the fact that the sample in the study are educated and majority of the parents are working may focus on their adolescent children by involving in their activities related to school and other than school, this might be the reason for adolescents personal and social identity. Hence the adolescents with high parental interest had personal and social identity.

Adolescents who are receiving high resources had high mean scores on social, relational and collective identity. This might be due to the reason that the sample selected for the study are belonging to urban area where the people lives in modern society with more understanding the children than other areas. The parents of adolescents were belonging to nuclear family and majority of the fathers were well educated and the economic status of the families were middle and upper middle income groups, are providing all the resources to the adolescents. Hence the adolescents with high resource provision had high social identity followed by relational and collective identity. 
Table-3 Mean difference between parental support system and dimensions of identity development among early adolescents $(\mathrm{N}=40)$

\begin{tabular}{|c|c|c|c|c|c|c|c|c|c|c|}
\hline \multirow[t]{2}{*}{ Sl.No } & \multirow{2}{*}{$\begin{array}{l}\text { Dimensions } \\
\text { of parental } \\
\text { support } \\
\text { system }\end{array}$} & \multicolumn{2}{|c|}{$\begin{array}{l}\text { Personal } \\
\text { identity }\end{array}$} & \multicolumn{2}{|c|}{$\begin{array}{l}\text { Relational } \\
\text { identity }\end{array}$} & \multicolumn{2}{|c|}{ Social identity } & \multicolumn{2}{|c|}{$\begin{array}{l}\text { Collective } \\
\text { identity }\end{array}$} & \multirow[t]{2}{*}{ F value } \\
\hline & & Mean & S.D & Mean & S.D & Mean & S.D & Mean & S.D & \\
\hline 1 & Interest & 2.99 & 0.5627 & 2.84 & 0.5988 & 2.85 & 0.5771 & 2.65 & 0.4087 & $0.003129 *$ \\
\hline 2 & Behaviour & 2.13 & 0.3942 & 2.22 & 0.4922 & 2.18 & 0.4598 & 2.36 & 0.5376 & 0.232998 \\
\hline 3 & $\begin{array}{l}\text { Resource } \\
\text { provision }\end{array}$ & 2.29 & 0.4662 & 2.36 & 0.4520 & 2.02 & 0.3097 & 2.59 & 0.5843 & 0.443278 \\
\hline
\end{tabular}

$* \mathbf{P},>0.05 ; * * \mathbf{P},>0.01$

The table three reveals the details of early adolescents mean differences between dimensions of parental support system and dimensions of identity development. It was clear from the table that there was a positive and significant relationship exists between the dimension of parental interest and identity development of early adolescent. The early adolescents had high mean scores on personal identity than other dimension. The other dimensions such as parent's behaviour and resource provision, there was not much differences were observed between parents support system and dimensions of identity development. This might be due to the fact that when children enter into adolescent period, parents are more curious about the children because of sudden physical changes, and also the friendships of early adolescents with same sex and opposite sex are more focused, due to these reasons parents might have shown much interest on early adolescents. Hence the early adolescents who perceived high parental interest had high mean scores on personal and social identity. 
Table-4 Mean difference between parental support system and dimensions of identity development among middle adolescents $\mathrm{N}=40$

\begin{tabular}{|c|c|c|c|c|c|c|c|c|c|c|}
\hline \multirow[t]{2}{*}{ Sl.No } & \multirow{2}{*}{$\begin{array}{l}\text { Dimensions } \\
\text { of parental } \\
\text { support } \\
\text { system }\end{array}$} & \multicolumn{2}{|c|}{$\begin{array}{l}\text { Personal } \\
\text { identity }\end{array}$} & \multicolumn{2}{|c|}{$\begin{array}{l}\text { Relational } \\
\text { identity }\end{array}$} & \multicolumn{2}{|c|}{ Social identity } & \multicolumn{2}{|c|}{$\begin{array}{l}\text { Collective } \\
\text { identity }\end{array}$} & \multirow[t]{2}{*}{ F value } \\
\hline & & Mean & S.D & Mean & S.D & Mean & S.D & Mean & S.D & \\
\hline 1 & Interest & 2.69 & 0.572 & 2.64 & 0.5588 & 2.87 & 0.5508 & 2.92 & 0.5887 & $0.002782 *$ \\
\hline 2 & Behaviour & 2.033 & 0.344 & 2.42 & 0.5426 & 2.58 & 0.5088 & 2.61 & 0.5290 & 0.24532 \\
\hline 3 & $\begin{array}{l}\text { Resource } \\
\text { provision }\end{array}$ & 2.49 & 0.496 & 2.74 & 0.5529 & 2.82 & 0.5099 & 2.45 & 0.5066 & 0.003247* \\
\hline
\end{tabular}

$* \mathbf{P},>0.05 ; * * \mathbf{P},>0.01$

The above table depicts the details of middle adolescents mean differences between the dimensions of perceived parental support system and dimensions of identity development. There was a significant and positive relationship exists between independent and dependent variable of middle adolescents i.e. between parental interest, resource provision and dimensions of identity development. It means the adolescents who viewed that their parents are showing interest and providing resources for their development had high mean scores on identity development dimensions. Middle adolescents had high mean scores on collective, identity and social identity with respect to parental interest. Regarding parental resource provision they had high mean scores on social and relational identity. It might be due to the fact that adolescence is a critical period for identity development based on their own strengths and weaknesses adolescents try to form their own identity, plans for future and career development. For this reason the parent might have provided enough resources and more concerned towards their children development. Hence it was clear from the results that middle adolescent who viewed that their parents are more supportive in terms of showing interest and providing resources for their development had high social and collective identity. 
A study on Differences between Parental Support System and Dimensions of Identity Development among Adolescents

Table-5 Mean difference between parental support system and dimensions of identity development among late adolescents $\quad(\mathrm{N}=40)$

\begin{tabular}{|c|c|c|c|c|c|c|c|c|c|c|}
\hline \multirow[t]{2}{*}{ Sl.No } & \multirow{2}{*}{$\begin{array}{l}\text { Dimensions } \\
\text { of parental } \\
\text { support } \\
\text { system }\end{array}$} & \multicolumn{2}{|c|}{$\begin{array}{l}\text { Personal } \\
\text { identity }\end{array}$} & \multicolumn{2}{|c|}{$\begin{array}{l}\text { Relational } \\
\text { identity }\end{array}$} & \multicolumn{2}{|c|}{$\begin{array}{l}\text { Social } \\
\text { identity }\end{array}$} & \multicolumn{2}{|c|}{$\begin{array}{l}\text { Collective } \\
\text { identity }\end{array}$} & \multirow[t]{2}{*}{ F value } \\
\hline & & Mean & S.D & Mean & S.D & Mean & S.D & Mean & S.D & \\
\hline 1 & Interest & 2.98 & 0.589 & 2.87 & 0.650 & 2.68 & 0.508 & 2.84 & 0.5995 & $0.006524 *$ \\
\hline 2 & Behaviour & 2.88 & 0.608 & 2.63 & 0.576 & 2.42 & 0.521 & 2.19 & 0.5495 & 0.355320 \\
\hline 3 & $\begin{array}{l}\text { Resource } \\
\text { provision }\end{array}$ & 2.76 & 0.589 & 2.22 & 0.534 & 2.76 & 0.573 & 2.34 & 0.5942 & 0.029187* \\
\hline
\end{tabular}

$* \mathbf{P},>0.05 ; * * \mathbf{P},>0.01$

The table four explains the results of mean differences between the dimensions of perceived parental support system and dimensions of identity development of later adolescents. It was observed from the table that, positive and significant relationship exists between later adolescents perceived parental interest, parental resource provision and dimensions of identity development. The later adolescents who received much of their parental interest and also resources had high mean scores on personal, relational and social identity. Hence the later adolescent who felt that their parents are more supportive in terms of showing interest and providing resources for their development had high personal, relational and collective identity.

\section{CONCLUSION}

The analysis of the findings revealed that, a positive and significant relationship exists between the dimension of parental support system and identity development of adolescents. Adolescents who are receiving their parents interest in various aspects of their life, had high mean scores on personal and social identity development compared to adolescents who perceived less satisfaction with their parents support and further the results of the study also depicted that adolescents who are receiving high resources from their parents had high mean scores on social, relational and collective identity. It means the two variables such as parental support system and identity development are associated to each other. Which means parental support system as perceived by adolescents would affect their identity development. 


\section{REFERENCES}

Bartle-Haring, 1997; Grotevant, 1998; Sartor\&Youniss, 2006. The impact of anxiety on Identity development in late adolescence and early adulthood. Journal of Adolescent Research, 17, 439-450.

Cheek, J. M., and Briggs, S. R. 2013. Aspects of Identity Questionnaire (AIQ-IV). Measurement Instrument Database for the Social Science. www.midss.ie

Erikson, E. H. 1968. Identity, youth and crisis. New York: W. W. Norton Company, Behavioral Science. 14(2):154-159.

Phinney,J., and Reis, D.K. 2009. Ethnic identity in adolescence: Process and context. International Journal of social behaviour and personality, 26(1): 79-87.

Rana and Shirali,. (2010). Identity and family functioning link: An investigation of Indian youth. Journal of Psychology, 36.266-271

Schmitt, D. P., Realo, A., Voracek, M., and Allik, J. 2008. Why can't a man be more like a woman? Sex differences in Big Five personality traits across 55 cultures. 94(1):168-82. 